Journal of

Cancer Research and Therapeutic Oncology

\title{
Systematic Review and Meta-Analysis of the Accuracy of Confocal Micros- copy in the Diagnosis of Skin Cancer
}

\author{
Rahman $\mathrm{A}^{1, *}$, Miller $\mathrm{S}^{2}$, Whittington $\mathrm{B}^{2}$, Tee $\mathrm{C}^{2}$, Mclellan $\mathrm{G}^{2}$, Cole $\mathrm{D}^{2}$, Spence $\mathrm{R}^{2}$, Rajpara $\mathrm{S}^{1,2}$ \\ ${ }^{1}$ Aberdeen Royal Infirmary, Foresterhill Aberdeen, Scotland, UK \\ ${ }^{2}$ University of Aberdeen, Aberdeen, UK \\ ${ }^{\star}$ Corresponding author: Dr. Atiya Rahman, 311, Street No 39, G 9/1 Islamabad, Pakistan ; Tel: 0923345252383; \\ Email: atiya_rahman7@yahoo.com
}

Received Date: March 13, 2015; Accepted Date: May 08, 2015; Published Date: May 11, 2015

Citation: Rahman A, et al.. (2015) Systematic Review and Meta-Analysis of the Accuracy of Confocal Microscopy in the Diagnosis of Skin Cancer. J Cancer Res Therap Oncol 1: 1-8.

\begin{abstract}
Background: Nonmelanoma skin cancer (Basal Cell Cancer (BCC) and Squamous Cell Cancer (SCC)) are the most prevalent cancer in the light-skinned population. The incidence of melanoma has been increasing steadily throughout the world. Early recognition of skin cancer without doing biopsy remains challenging. The development of noninvasive diagnostic technologies is highly relevant and desired. Confocal Laser Scanning Microscopy (CLSM) enables in vivo and ex vivo imaging of human skin at a quasi-histologic resolution.

Methods and Materials: Several databases like Medline, Embase, all EBM reviews (ACP Journal Club, Cochrane Controlled Trials Register, Cochrane Database of Systematic Reviews, Database of Abstracts of Reviews of Effects) and Journals@Ovid were used to perform a literature search on CLSM in the diagnosis of melanoma and non melanoma skin cancers. Standards for Reporting of Diagnosis Accuracy (STARD) initiative checklist and National Institute for Health and Clinical Excellence (NICE) guidelines on methodology were used to assess the quality of the studies found. Eight studies fulfilling relevant criteria inclusive of assessment of diagnostic accuracy of CSLM and histopathology were selected. Heterogeneity among the studies was assessed and the data was pooled for meta- analysis.

Results: The eight included studies did not have considerable heterogeneity between them. The pooled sensitivity for melanoma diagnosis was $91.4 \%$ and for BCC diagnosis was $90.1 \%$. Pooled specificities were $79.9 \%$ and $92.6 \%$ for malignant melanoma and BCC respectively. Diagnostic odds ratios for melanoma and BCC were 80.1 and 358.1 respectively.

Conclusions: From the limited good quality available literature we found that CLSM has the potential to be an additional noninvasive diagnostic test to dermoscopy for the diagnosis of BCC and melanoma.
\end{abstract}

\section{Introduction}

The incidence of non melanoma skin cancer, BCC and SCC has increased by $10 \%$ per annum; with $2-3$ million new cases diagnosed worldwide each year [1]. Worldwide the incidence of melanoma is increasing faster than any other cancer, with rates doubling every 10-20 years in the Caucasian population. In the UK the incidence of melanoma has quadrupled over the last 40 years [2].

Early diagnosis is of utmost importance in the management of skin cancers to prevent or minimize the morbidity and mortality associated with them. In specialized centres the accuracy of clinical diagnosis, on the basis of an unaided eye, of melanoma is only around 60\% [3]. Histology remains the gold standard for the diagnosis of skin cancers. Various non

(C)2015 The Authors. Published by the JScholar under the terms of the Creative Commons Attribution License http://creativecommons.org/licenses/ by $/ 3.0 /$, which permits unrestricted use, provided the original author and source are credited. invasive methods like dermoscopy [4,5], Raman spectroscopy [6], CLSM [7] and others like positron emission tomography, ultrasonography, Doppler, computed tomography, magnetic resonance imaging, optical coherence tomography and terahertz imaging have been used to improve the diagnostic performance. Out of these, dermoscopy has been in routine use for the diagnosis of the skin cancer. It provides a non invasive, rapid, in vivo examination of the superficial layers of the skin. It has a sensitivity and specificity of $86 \%$ and $89 \%$ respectively for cutaneous melanoma [5]. The requirement to develop a better imaging tool remains. CLSM, a non-invasive diagnostic tool, was first reported in 1995 to be used in vivo on human tissue [8]. Since then, there has been many studies evaluating its role in viewing the microscopic features of normal skin [9] and various lesions such as cutaneous neoplasms $[10,11]$, pigmented lesions [12,13,14], actinic keratosis [15], sebaceous gland hyperplasia [16], psoriasis [17], irritant and allergic contact dermatitis $[18,19]$. CLSM can distinguish melanocytes from other pigmented lesions like pigmented 
keratinocytes and melanophages [20]. Typical CLSM has a lateral resolution of $0.5-1 \mu \mathrm{m}$ and axial resolution of 3-5 $\mu \mathrm{m}$ providing horizontal sections similar to thickness of histology sections. Maximum penetration of the skin is $350 \mu \mathrm{m}[21,22]$. Different skin cancers have different morphological features which can be distinguished by using CLSM in vivo and ex vivo, enabling it to be potentially used to give a real time diagnosis to the patients negating the need to wait for histopathology results $[22,23]$. There are many articles but only a limited number of studies on the use of CLSM in the diagnosis of skin cancer. A systematic review was done to do an objective assessment of the available evidence.

\section{Aim and Objective}

The scope of this systematic review and meta analysis is to examine the diagnostic accuracy of CLSM in skin cancers in the selected studies which have met the inclusion criteria.

\section{Materials and Methods}

\section{Search strategy}

A comprehensive literature search of Medline (from 1950 to July 2013), Embase (from 1980 to August 2013), and all EBM reviews (ACP Journal Club, Cochrane Controlled Trials Register, Cochrane Database of Systematic Reviews, Database of Abstracts of Reviews of Effects) and Journals@Ovid was carried out using the following key words or corresponding MeSH terms: confocal microscopy, confocal laser scanning microscopy, reflectance confocal microscopy, confocal microscopy and skin cancer, confocal microscopy and histology, confocal microscopy and skin cancer and histology, to identify original studies, abstracts and systematic reviews. The resultant hits performed on $17^{\text {th }}$ August 2013 are shown in Table 1. Studies fulfilling the following inclusion criteria were included without any language or time restrictions.

\section{Type of studies}

Original prospective and retrospective studies were included. These were the principal published reports of original data from case control or cohort studies and were independent from other studies to avoid including the results from the same study twice.

\section{Target conditions}

Melanoma and nonmelanoma skin cancers i.e. BCC and SCC.

\section{Study population}

The selected studies involved humans of any age, sex and ethnic group, and performed at primary, secondary or tertiary levels of healthcare involving equal to or more than 10 subjects.

\section{Intervention}

Confocal laser scanning microscopy (CLSM).

\section{Reference standard}

Histopathology of the excised skin lesions.

\section{Study results}

The studies reporting results in the form of true positives (TP), true negatives (TN), false negatives (FN) and false positives (FP) or results from which these values could be computed was included. Where a study showed different sensitivity and specificity values by taking into account different criteria, the results with the highest values were included for review.

\section{Methodological quality}

Assessment of the quality of articles was undertaken by AR, SM, CT, BW, GM, DC, RS and SR. 120 citations were identified as relevant to the topic. The titles and abstracts of all 120 retrieved articles were divided amongst the first 7 authors and were reviewed independently by them and then in the group with SR. Where the abstract was not available, full-text articles were retrieved for further evaluation. 56 citations were excluded after duplication or the title and/or abstract were not relevant for the end point of the study. In this way, 64 full text articles were assessed for eligibility. The methodological quality of the studies was assessed by the group independently and then together with SR with Standards for Reporting of Diagnosis Accuracy (STARD) initiative [24]. This checklist and National Institute for Health and Clinical Excellence (NICE) guidelines on methodology, checklist for diagnostic studies[25] formed basis for this review and meta-analysis. Reviews, editorials, case reports, small case series and studies that were derivation studies, i.e. not done on new set of patients were excluded. Finally eight studies [21,26-32] met the criteria to be included for meta analysis. The evidence level of the studies was determined as per the NICE guidelines on development methods [33].

\section{Data collection}

Data from the eligible studies were extracted in a table adapted from NICE guidelines [34] (Table 1 and 2).

\section{Data analysis}

Meta-analysis was carried out using Meta-DiSc (available at: http://www.hrc.es/investigacion/metadisc_en.htm) version 1.4. For sensitivity and specificity of the included studies, hetereogeneity was tested by using likelihood ratio tests, shown as $a \mathrm{x}^{2}$ value on the forest plots. For the positive and negative likelihood ratios and DORs homogeneity was tested using Cochran's $\mathrm{Q}$. The possibility of heterogeneity being due to use of different thresholds in different studies were investigated by plotting sensitivities and specificities from the studies as points on an SROC curves.

\begin{tabular}{|l|l|l|l|l|}
\hline Key words & $\begin{array}{l}\text { Ovid } \\
\text { embase }\end{array}$ & $\begin{array}{l}\text { Ovid } \\
\text { medline }\end{array}$ & Pubmed & Cochrane \\
\hline Confocal microscopy & 11769 & 9221 & 57839 & 0 \\
\hline $\begin{array}{l}\text { Confocal laser scanning } \\
\text { microscopy }\end{array}$ & 2010 & 1436 & 57839 & 0 \\
\hline $\begin{array}{l}\text { Reflectance confocal } \\
\text { microscopy }\end{array}$ & 102 & 146 & 607 & 0 \\
\hline $\begin{array}{l}\text { Confocal microscopy and } \\
\text { skin cancer }\end{array}$ & 34 & 50 & 461 & 0 \\
\hline $\begin{array}{l}\text { Confocal microscopy and } \\
\text { histology }\end{array}$ & 500 & 399 & 32157 & 0 \\
\hline $\begin{array}{l}\text { Confocal microscopy and } \\
\text { skin cancer and histology }\end{array}$ & 3 & 4 & 358 & 0 \\
\hline
\end{tabular}

Table 1: The number of hits obtained from each database when searching for articles using key words 


\begin{tabular}{|c|c|c|c|c|c|c|c|c|c|c|}
\hline $\begin{array}{l}\text { Ser. } \\
\text { No }\end{array}$ & Study Author & Study Type & $\begin{array}{l}\text { Evi- } \\
\text { dence } \\
\text { Level }\end{array}$ & $\begin{array}{l}\text { Type Of } \\
\text { Tech- } \\
\text { nique } \\
\text { Used }\end{array}$ & $\begin{array}{l}\text { Number Of } \\
\text { Skin Cancer } \\
\text { Lesions }\end{array}$ & $\begin{array}{l}\text { Total } \\
\text { Number } \\
\text { Of } \\
\text { Lesions }\end{array}$ & $\begin{array}{l}\text { Reference } \\
\text { Standard }\end{array}$ & $\begin{array}{l}\text { Blind- } \\
\text { ing }\end{array}$ & $\begin{array}{l}\text { Number } \\
\text { Of Patients }\end{array}$ & Patient Characteristics \\
\hline 1 & $\begin{array}{l}\text { Nori S et al., } \\
2004[21]\end{array}$ & $\begin{array}{l}\text { Retrospec- } \\
\text { tive }\end{array}$ & $\mathrm{Ib}$ & $\begin{array}{l}\text { In vivo } \\
\mathrm{CM}\end{array}$ & 83 & 137 & Histology & yes & 145 & $\begin{array}{l}\text { Lesions } 98 \text { male specimens, } 54 \\
\text { female specimen }\end{array}$ \\
\hline 2 & $\begin{array}{l}\text { Horn } M \text { et } \\
\text { al., } 2006[26]\end{array}$ & $\begin{array}{l}\text { Retrospec- } \\
\text { tive }\end{array}$ & II & $\begin{array}{l}\text { Ex vivo } \\
\mathrm{CM}\end{array}$ & 20 & 40 & Histology & yes & 20 & Not described \\
\hline 3 & $\begin{array}{l}\text { Gerger A et } \\
\text { al., } 2005[27]\end{array}$ & $\begin{array}{l}\text { Prospec- } \\
\text { tive }\end{array}$ & II & $\begin{array}{l}\text { In vivo } \\
\mathrm{CM}\end{array}$ & 27 & 57 & Histology & yes & 57 & $\begin{array}{l}\text { Gender and age not mentioned. } \\
\text { Location of lesions given as } 15 \\
\text { on back, } 6 \text { on legs, } 4 \text { on head } \\
\text { and } 1 \text { on acral skin }\end{array}$ \\
\hline 4 & $\begin{array}{l}\text { Langley R et } \\
\text { al., } 2007[28]\end{array}$ & $\begin{array}{l}\text { Prospec- } \\
\text { tive }\end{array}$ & II & $\begin{array}{l}\text { In vivo } \\
\mathrm{CM}\end{array}$ & 37 & 125 & Histology & no & 125 & $\begin{array}{l}\text { Age range } 16-84 \text { yrs, mean age } \\
44.2 \text {, no gender statistics }\end{array}$ \\
\hline 5 & $\begin{array}{l}\text { Guitera P et } \\
\text { al., } 2010[29]\end{array}$ & $\begin{array}{l}\text { Retrospec- } \\
\text { tive }\end{array}$ & II & $\begin{array}{l}\text { In vivo } \\
\mathrm{CM}\end{array}$ & 29 & 73 & Histology & yes & 73 & Not described for test set \\
\hline 6 & $\begin{array}{l}\text { Curchin C et } \\
\text { al., } 2011[32]\end{array}$ & $\begin{array}{l}\text { Retrospec- } \\
\text { tive }\end{array}$ & $\mathrm{Ib}$ & $\begin{array}{l}\text { In vivo } \\
\mathrm{CM}\end{array}$ & $\begin{array}{l}13 \mathrm{MM} \\
9 \mathrm{BCC}\end{array}$ & 50 & Histology & yes & 42 & Not described \\
\hline 7 & $\begin{array}{l}\text { Longo C et } \\
\text { al., } 2013[30]\end{array}$ & $\begin{array}{l}\text { Retrospec- } \\
\text { tive }\end{array}$ & II & $\begin{array}{l}\text { In vivo } \\
\mathrm{CM}\end{array}$ & $\begin{array}{l}32 \mathrm{MM} \\
28 \text { BCC } \\
6 \text { SCC }\end{array}$ & 140 & Histology & yes & 140 & 64 male, 76 female \\
\hline 8 & $\begin{array}{l}\text { Guitera P et } \\
\text { al., } 2012[31]\end{array}$ & $\begin{array}{l}\text { Retrospec- } \\
\text { tive }\end{array}$ & II & $\begin{array}{l}\text { In vivo } \\
\mathrm{CM}\end{array}$ & $\begin{array}{l}105 \mathrm{MM} \\
52 \mathrm{BCC}\end{array}$ & 356 & Histology & yes & $\begin{array}{l}\text { Not Avail- } \\
\text { able }\end{array}$ & $\begin{array}{l}\text { Total } 663 \text { patients, } 309 \text { females } \\
\text { and } 354 \text { males. Median age } 53 \\
\text { yrs. But patient characteristics } \\
\text { not described separately for } \\
\text { test set }\end{array}$ \\
\hline
\end{tabular}

*both cancerous and non cancerous

Table 2: Tabulated form of variables collected from the included studies

\section{Results}

\section{Methodological quality}

Eight studies fulfilling majority, which is 13 or more, of the criteria in STARD checklist [24] were included in the systematic review. In a study by Nori $\mathrm{S}$ et al. sensitivity and specificity were calculated by using 1-5 criteria's of CLSM [21]. We used sensitivity and specificity values for 4 or more criteria's from this study as they give optimum sensitivity and specificity.

\section{Included studies}

All studies were published as original articles in the English language and were conducted at tertiary care settings in the Europe, North America and Australia. Demography and study characteristics are shown in Table 1. Average sensitivity, specificity, positive and negative predictive values from these studies is shown in Table 2. All selected studies had CLSM done on either a single or more than one type of skin cancer and normal peri-lesional skin [26] and/or benign lesions [21,27-32]. The skin cancers included melanoma, BCC and SCC and the benign lesions included seborrheic keratosis [21,30], benign melanocytic lesions [21,27-32], actinic keratosis [21,29,31,32], sebaceous hyperplasia[21], acne[21], rosacea[21], wart[21], molluscum contagiosum[21], cutaneous T cell lymphoma[21], eczema[21, dermatofibroma[21,30,31], tinea[21], vascular lesions[30] and Bowen's disease[31] etc. Five studies[21,26-29] were done on one type of skin cancer. In 3 studies more than one skin cancer was included in the study population [30-32]. The study by Longo $\mathrm{C}$ et al.[30] included all 3 types of skin cancer i.e. malignant melanoma, BCC and SCC. Guitera P et al. [31] devised MM and BCC algorithms. Studies by Curchin $\mathrm{C}$ et al. [32] and Guitera P et al. [31] grouped lesions of SCC together with pre malignant condition, actinic keratosis, so the results were not used in meta-analysis.

All the included studies compared CLSM results with histopathology, which is considered the "gold standard". In the studies $[21,27]$ where histopathology was not done on all the lesions only the histopathologically confirmed lesions were included in the meta-analysis. In order to carry out meta-analysis the studies were split into three groups depending on the type of cancer that CLSM was used to detect. There were only two studies for the diagnosis of SCC $[26,30]$, four and six studies for BCC [21,30-32] and melanoma [27-32] respectively . The results of the studies for BCC and melanoma were pooled separately, as they were of clinically similar patients and methodologies. The two included studies on SCC only had a total of 26 lesions; as the data is scanty meta-analysis was not done. However, SCC has been included in the Tables 2 and 3. Results of meta-analysis are shown in Table 4 and Figures 1-6.

\section{Sensitivity}

Sensitivity is the proportion of positives among people with disease. The pooled sensitivity for melanoma diagnosis was 91.4\% [95\% Confidence Interval (CI), 87.1\%-94.6\%] and for BCC diagnosis was 90.1\% [95\% CI, 84.6\%-94.1\%] (figure 1 $\mathrm{a} \& \mathrm{~b})$.

\section{Specificity}

Specificity can be defined as proportion of negatives among people without disease. Pooled specificities were 79.9\% [95\% CI, 76.4\%-83.2\%] and 92.6\% [95\% CI, 89.9\% - 94.7\%] for malignant melanoma and BCC respectively (figure $2 \mathrm{a} \& \mathrm{~b}$ ).

\section{Likelihood ratios}

The positive likelihood ratio (LR) indicates how many times more likely a particular test result is, in subjects with the disease compared to those without the disease. The higher the 


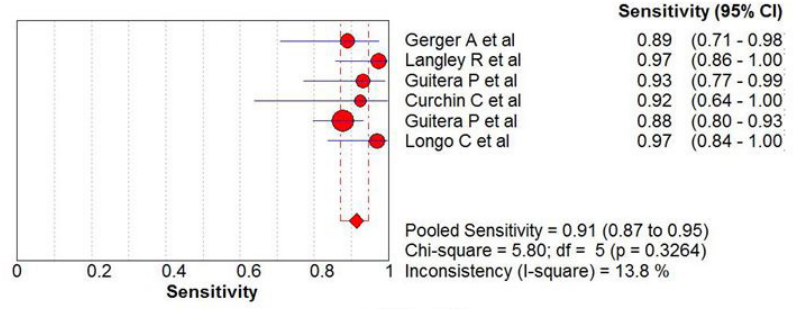

Figure 1 (a)

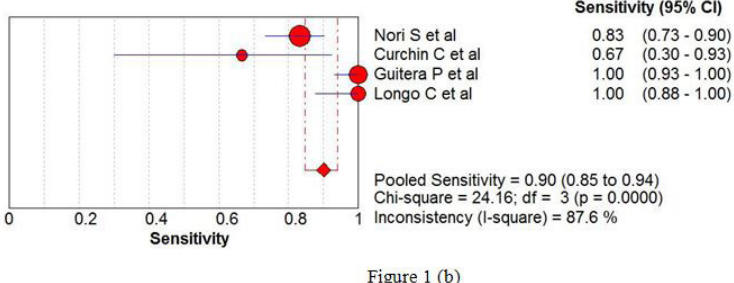

Figure 1: Sensitivity of CLSM in the diagnosis of (a) Malignant Melanoma and (b) Basal Cell Carcinoma.
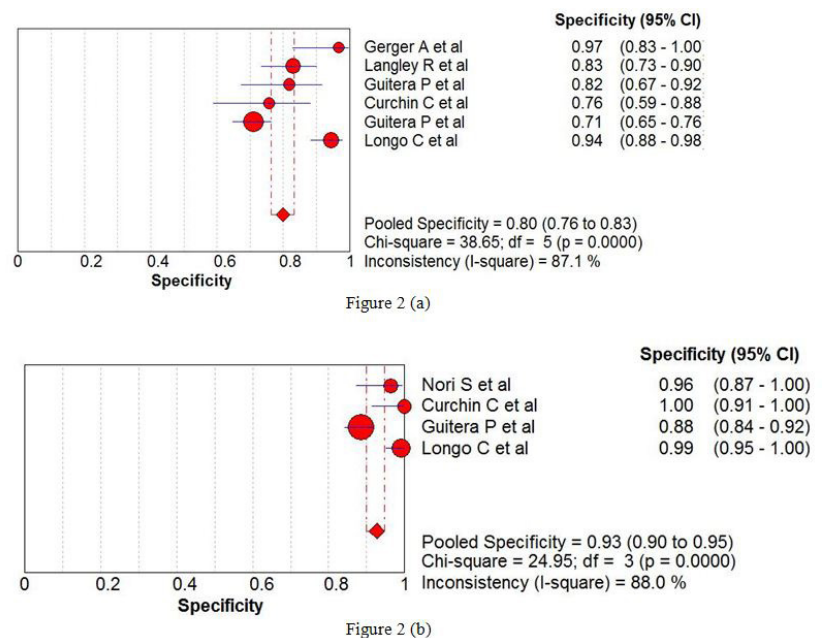

Figure 2: Specificity of CLSM in the diagnosis of (a) Malignant Melanoma and (b) Basal Cell Carcinoma.
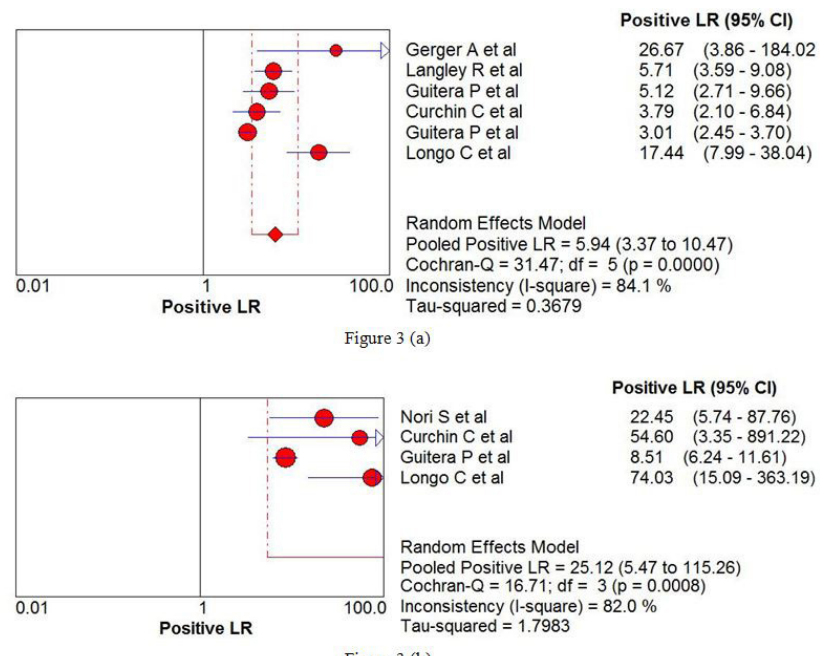

Figure 3: Positive likelihood ratio of CLSM in the diagnosis of (a) Malignant Melanoma and (b) Basal Cell Carcinoma.
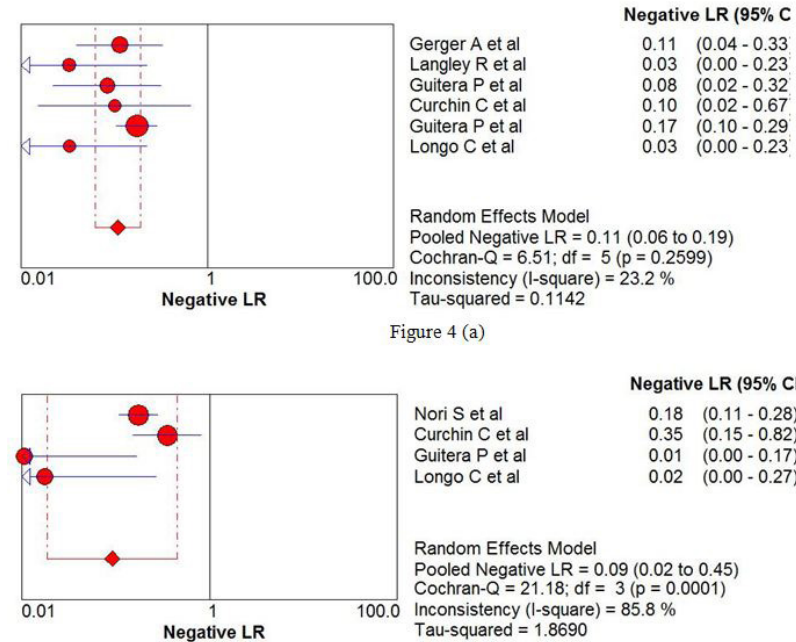

Figure 4: Negative likelihood ratio of CLSM in the diagnosis of (a) Malignant Melanoma and (b) Basal Cell Carcinoma.
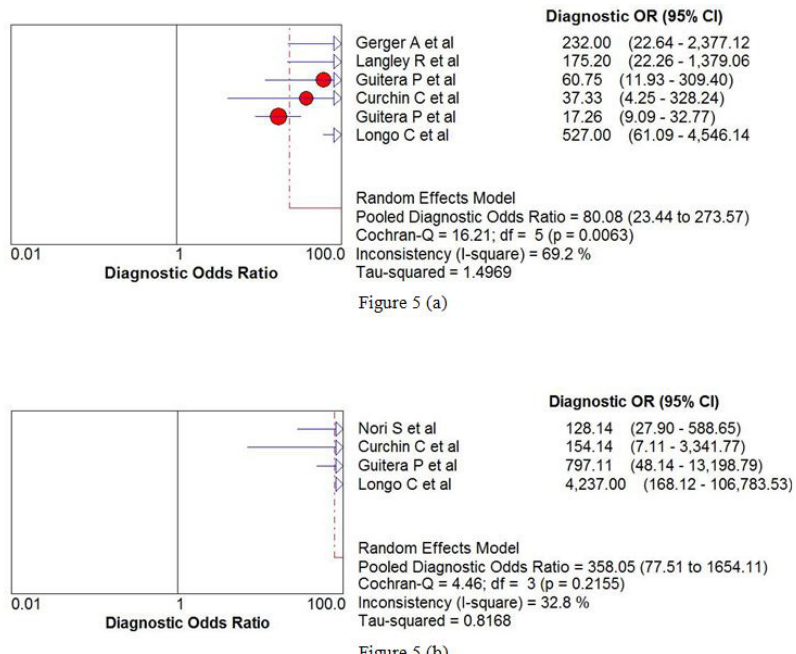

Figure 5: Diagnostic odds ratio of CLSM in the diagnosis of (a) Malignant Melanoma and (b) Basal Cell Carcinoma.

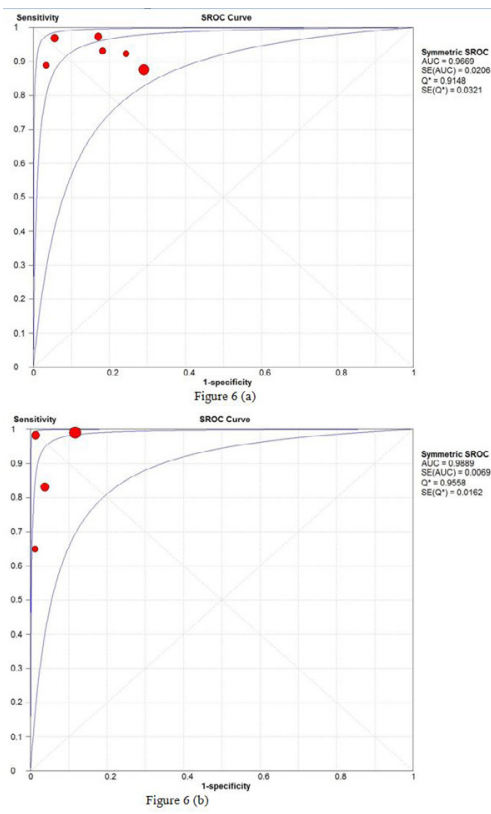

Figure 6: SROC curve of CLSM for diagnosing (a) Malignant Melanoma and (b) Basal Cell Carcinoma. 


\begin{tabular}{|l|l|l|l|l|l|l|}
\hline $\begin{array}{l}\text { Ser. } \\
\text { No }\end{array}$ & Studies & $\begin{array}{l}\text { Type of } \\
\text { Skin cancer }\end{array}$ & $\begin{array}{l}\text { Average sensitiv- } \\
\text { ity (\%) }\end{array}$ & $\begin{array}{l}\text { Average Specificity } \\
(\%)\end{array}$ & $\begin{array}{l}\text { Average PPV } \\
\text { (Positive Predictive Value \%) }\end{array}$ & $\begin{array}{l}\text { Average NPV } \\
\text { (Negative Predictive Value \%) }\end{array}$ \\
\hline 1 & Nori S et al., 2004 [21] & BCC & 82.9 & 95.7 & 97.18 & 78.79 \\
\hline 2 & Horn M et al., 2006 [26] & SCC & 95 & 96.25 & 96.20 & 95.06 \\
\hline 3 & Gerger A et al., 2005 [27] & Melanoma & 88.15 & 97.60 & 96 & 90.63 \\
\hline 4 & Langley R et al.,2007 [28] & Melanoma & 97.3 & 83 & 70.59 & 98.65 \\
\hline 5 & Guitera P et al.,2010 [29] & Melanoma & 93 & 82 & 77.14 & 94.74 \\
\hline 6 & Curchin C et al. [32] & Melanoma & 92.3 & 75 & 52.17 & 96.55 \\
\cline { 3 - 7 } & & BCC & 66.7 & 100 & 100 & 93.18 \\
\hline 7 & \multirow{2}{*}{ Longo C et al., 2013 [30] } & Melanoma & 92.3 & 75 & 52.17 & 96.55 \\
\cline { 3 - 7 } & & BCC & 100 & 99.1 & 96.55 & 100 \\
\cline { 3 - 7 } & & SCC & 78.12 & 87 & 21.62 & 98.89 \\
\hline \multirow{2}{*}{8} & \multirow{2}{*}{ Guitera P et al., 2012 [31] } & Melanoma & 87.6 & 70.8 & 55.76 & 93.19 \\
\cline { 3 - 7 } & & BCC & 100 & 88.5 & 59.77 & 100 \\
\hline
\end{tabular}

Table 3: Table showing sensitivities, specificities, PPV and NPV of the included studies.

\begin{tabular}{|l|l|l|l|l|l|l|l|l|l|l|}
\hline Skin Cancer type & \multicolumn{2}{|c|}{ Pooled Sensitivity } & \multicolumn{2}{|c|}{ Pooled Specificity } & \multicolumn{2}{c|}{ Pooled Positive LR } & \multicolumn{2}{c|}{ Pooled Negative LR } & \multicolumn{2}{c|}{ Pooled DOR } \\
\hline & Value & $95 \%$ CI & Value & $95 \%$ CI & Value & $95 \%$ CI & Value & $95 \%$ CI & Value & $95 \%$ CI \\
\hline Melanoma & 0.914 & $0.871-0.946$ & 0.799 & $0.764-0.832$ & 5.935 & $3.366-10.466$ & 0.109 & $0.062-0.190$ & 80.075 & $23.438-273.57$ \\
\hline $\begin{array}{l}\text { Basal Cell Carci- } \\
\text { noma }\end{array}$ & 0.901 & $0.846-0.941$ & 0.926 & $0.899-0.947$ & 25.117 & $5.474-115.256$ & 0.092 & $0.019-0.449$ & 358.05 & $77.505-1654.1$ \\
\hline
\end{tabular}

Table 4: Table showing pooled sensitivities, specificities, LR and DOR of the included studies.

positive LR the test the more indicative of disease it is. It is considered a good diagnostic test if the value is 10 or above [36]. Pooled positive LR for BCC was 25.18 and for melanoma it was 5.94 (Figure 3a \& Figure 3b). The negative LR is a good indicator for a tests ability to rule out a diagnosis. A good diagnostic test has a value of $<0.1$ and as shown in the figures 4 $\mathrm{a} \& \mathrm{~b}$, CLSM has a negative LR of 0.11 and 0.09 for melanoma and $\mathrm{BCC}$ respectively.

\section{Diagnostic Odds Ratio}

DOR expresses how much greater the odds of having the disease are for the people with a positive test result than for the people with a negative test result. DOR is a convenient measure when combining studies in a systematic review. The pooled DOR can range from $<1$ to infinity with the higher results showing a higher discriminatory test [37]. DOR for melanoma and BCC were 80.08 and 358.05 respectively (Figure 5a \& Figure 5b).

\section{Summary Receiver Operating Characteristic (SROC) Curve}

The shape of a ROC curve and the area under the curve (AUC) helps us estimate how high the discriminative power of a test is. The closer the curve is located to upper-left hand corner and the larger the area under the curve, the better the test is at discriminating between diseased and non-diseased. The area under the curve can have any value between 0 and 1 and it is a good indicator of the goodness of the test. A perfect diagnostic test has an AUC 1.0 Separate SROC curves were plotted for the studies on malignant melanoma and BCC (Figure 6a \& Figure $6 \mathrm{~b})$. Each point in the figures represents a different study and the size of the circle reflects the number of lesions included in the study. CLSM has an AUC of 0.97 for melanoma and 0.99 for BCC which indicates an excellent diagnostic accuracy of the instrument.

\section{Discussion}

Skin cancer is the most prevalent cancer in the light-skinned population. Histopathology remains the gold standard for the diagnosis till date. Over a period of time there have been various diagnostic tests and technologies developed and tried [38]. Reflectance CM or CLSM has the highest resolution of all optical techniques used in skin cancer diagnosis research [39].

In the studies included in meta-analysis the authors have used different pre defined scoring system or system of diagnosis. Gerger et al. [27] validated CLSM in diagnosing melanoma using the diagnostic morphologic features previously described by Busam et al. [20,40,41] and Langley et al. [42]. Langley et al. [28] used the criteria to establish a CLSM diagnosis of melanoma and naevi they had described previously in their initial series [42]. Curchin C et al. [32] followed the algorithms developed by Pellacani et al. [43] for melanoma and by Guitera $P$ et al. [29] for lentigo maligna. Guitera P et al. [29] worked on lentigo maligna (LM) and identified which CM features mentioned by Pellacani et al. [44] can distinguish LM from benign macules. Their study showed six features were independently correlated with malignancy by means of discriminant analysis and they termed them as LM Score. Longo C et al. [30] used 36 RCM criteria according to distinct diagnosis including melanoma, BCC, SCC, seborrhoeic keratosis, dermatofibroma, vascular lesions and xanthogranuloma. Significant RCM features for nodular melanoma and metstatic nodules were pagetoid distribution, cytological atypia and dermal nesting. Guitera $P$ et al. [31] identified 7 independently significant features for the diagnosis of MM. They include cerebriform nests, atypical cobblestone with small nucleated cells, marked cytologic atypia, pageoid cells, epidermal disarray, large interpapillary space and dense nest. Interestingly, pagetoid cells should be viewed with caution as work by Hashemi P [45] emphasizes that intraepidermal Langerhans cells are difficult to differenti- 
ate from melanocytes under Reflectance Confocal Microscopy (RCM) and their presence may simulate pagetoid spread of melanocytes on RCM images.

A model for the diagnosis of Basal Cell Carcinoma (BCC) with RCM described by Nori et al. [21] is based on the RCM features of an early version of the microscope, which is not in current widespread use. Segura $S$ et al. $[46,47]$ defined a two-step method for diagnosis, whereby at first, melanocytic lesions were distinguished from non-melanocytic lesions, and second, criteria were then applied to differentiate melanomas (MMs) from naevi. Although the authors described RCM features of BCCs, based on the analysis of 26 cases, the typical clinical cases of BCCs were not excised, and hence, the diagnosis of each case was not confirmed pathologically and could not be included in the review. Guitera P et al. [31] defined a model for accurately diagnosing BCCs studying 119 lesions. Their work represents the largest such series reported to date. The significant features distinguishing BCC from other leasions include polarized honeycomb appearance, linear telangiectasia-like horizontal vessels, basaloid cord or nodule, epidermal shadow, convoluted glomerular-like vessels, non-visible papillae, cerebriform nests, disarray of the epidermal layer. Longo $\mathrm{C}$ et al. [30] identified cauliflower architecture, BCC islands (dark silhouettes / tightly packed basaloid islands), bright filaments within tumour islands and collagen as significant features.

Because of the paucity of cases of SCC the results should be viewed with caution. However, work by Horn $\mathrm{M}$ et al. [26] and Longo $\mathrm{C}$ et al. [30] have provided the foundation for the future researchers. Morphological CLSM features of SCC were assessed according to standard criteria used in conventional histopathology by Horn $\mathrm{M}$ et al. [26]. The most frequent finding in SCC found by Longo C et al. [30] was the presence of a disarrayed epidermis, present in five out of six cases (83.3\%).

Amongst non-invasive diagnostic methods for skin cancers only dermoscopy is in regular clinical use and has been shown to have pooled sensitivity of 0.88 and specificity of 0.86 and pooled diagnostic odds ratio of 51.5 for the diagnosis of melanoma [5]. Although used for clinical diagnosis of BCC, dermoscopy has not been evaluated systematically for this purpose. As compared to naked eye examination, dermoscopy has ability to see through the stratum cormeum and outer layers of the epidermis. The advantage of dermoscopy is that it is a convenient hand held instrument. It is a simple and quick method which takes up to a minute to be performed, while CLSM takes considerably more time about 5-15 minutes for a single lesion [9].

In this review the pooled sensitivities, specificities and DORs of melanoma and BCC show the superiority of CLSM over dermoscopy on accurate diagnosis of these two types of skin cancers. Results for BCC are more impressive than for melanoma. This relies on the researches done by Longo C et al. [30] and Guitera P et al. [31], published in 2013 and 2012 respectively both of whom have shown $100 \%$ sensitivity of CLSM for BCC diagnosis. Curchin et al. [32] found CLSM to be $100 \%$ specific for BCC. DOR of 358.05 for BCC is quite remarkable and so is DOR of 80.08 for melanoma. The results of the review, thus, show that CLSM has the potential to be an aid in the diagnosis of skin cancers. Whereas treatment has hitherto been almost synonymous with surgery, new noninvasive treatment strategies call for noninvasive diagnostics. CLSM stands out among the new armamentarium of dermatologists because of its high resolution providing a "quasi histologic" skin examination at the bedside $[40,41]$. CLSM is limited by the depth of imaging restricted to the papillary dermis. Processes in the reticular dermis and tumour invasion depth cannot be evaluated reliably. Pathologic changes such as stratum corneum disruption, parakeratosis, ulceration and spongiosis may all further increase spherical aberration and laser light scattering and, therefore, reduce the resolution and maximum depth of imaging [19,30].

Stevenson et al. [48] have conducted a systematic review on the diagnostic accuracy of CLSM for melanoma diagnosis recently and they found CLSM 93\% (95\% CI 89 - 96) sensitive and 76\% (95\% CI 68 - 83) specific for melanoma diagnosis indicating the potential of the instrument to be used as an addson test for melanoma diagnosis. Our review shows slightly higher specificity as it includes the 2013 study by Longo C et al. [30] which found the instrument $100 \%$ specific. CLSM has impressive diagnostic performance, however, for the instrument to be routinely used CLSM needs to be smaller in size, less costly and be an operator friendly instrument.

\section{Conclusion}

CLSM enables in vivo and ex vivo imaging of human skin at a quasi-histologic resolution. Our review has shown that CLSM has very good diagnostic accuracy for BCC and melanoma based on limited number of studies. CLSM has the potential to be a useful diagnostic aid for skin cancers in the clinical settings.

Larger better designed studies should evaluate this potential further and also compare that with dermoscopy.

\section{Limitations of this review}

1. Although there is a good deal of literature on confocal microscopy use for the skin cancer diagnosis, only a small number of good quality studies have been done.

2. All studies were done at tertiary referral centers and not in the community.

\section{References}

1) Samarasinghe V, Madan V ( 2012) Non Melanoma Skin Cancer. J Cutan Aesthet Surg 5: 3-10.

2) Walter F, Morris H, Humphreys E, Hall PN, Prevost AT, et al. (2012) Effect of adding a diagnostic aid to best practice to manage suspicious pigmented lesions in primary care: A randomised controlled trial. BMJ 345:e4110.

3) Grin CM, Kopf AW, Welkovich B, Bart RS, Levenstein MJ (1990) Accuracy in the clinical diagnosis of malignant melanoma. Arch Dermatol 126: 763-766.

4) Wang SQ, Hasheni P (2010) Non Invasive Imaging technologies in the diagnosis of melanoma. Semin Cutan Med Surg 29:174-184

5) Rajpara SM, Botello PZ, Townsend J, Ormerod AD (2009) Systematic review of dermoscopy and digital dermoscopy/artificial intelligence for the diagnosis of melanoma. Br J Dermatol 161: 591-604. 
6) Silveira L Jr, Silveira FL, Bodanese B, Zângaro RA, Pacheco MT (2012) Discriminating model for diagnosis of basal cell carcinoma and melanoma in vitro based on the Raman spectra of selected biochemicals. J Biomed Opt 17: 077003.

7) Eichert S, Mohrle M, Breuninger H, Röcken M, Garbe C, et al. (2010) Diagnosis of cutaneous tumours with in vivo confocal laser scanning microscopy. J Dtsch Dermatol Ges 8: 400-410.

8) Rajadhyaksha M, Grossman M, Esterowitz D, Webb RH, Anderson RA (1995) In vivo confocal scanning laser microscopy of human skin: melanin provides strong contrast. J Invest Dermatol 104: 946-952.

9) Huzaira M, Rius F, Rajadhyaksha M, Anderson RR, González S (2001) Topographic variations in normal skin histology, as viewed by in vivo confocal microscopy. J Invest Dermatol. 116: 846-852.

10) Busam KJ, Hester K, Charles C, Sachs DL, Antonescu CR, et al. (2001) Detection of clinically amelanotic malignant melanoma and assessment of its margins by in vivo confocal scanning laser microscopy. Arch Dermatol 137: 923-929.

11) Sauermann K, Gambichler T, Wilmert M, Rotterdam S, Stücker $\mathrm{M}$, et al. (2002) Investigation of basal cell carcinoma by confocal laser scanning microscopy in vivo. Skin Res Technol 8:141-147.

12) Busam KJ1, Charles C, Lohmann CM, Marghoob A, Goldgeier M, et al. (2001) Detection of intraepidermal malignant melanoma in vivo by confocal scanning laser microscopy. Melanoma Res 12: 349-355.

13) Langley RG, Burton E, Walsh N, Propperova I, Murray SJ (2006) In vivo confocal scanning laser microscopy of benign lenitgenes: Comparison to conventional histology and in vivo characteristics of lentigo maligna. J Am Acad Dermatol 55: 88-97.

14) Charles CA, Marghoob AA, Busam KJ, Clark-Loeser L, Halpern AC (2002) Melanoma of pigmented Basal Cell Carcinoma: a clinicalpathological correlation with dermoscopy, in vivo confocal scanning laser microscopy, and routine histology. Skin Res Technol 8: 282-287.

15) Aghassi D, Anderson RR, Gonza'lez S (2000) Confocal laser microscopic imaging of actinic keratoses in vivo: a preliminary report. J Am Acad Dermatol 43: 42-48.

16) González S, White WM, Rajadhyaksha M, Anderson RR, González E (1999) Confocal imaging of sebaceous gland hyperplasia in vivo to assess efficacy and mechanism of pulsed dye laser treatment. Lasers Surg Med 25: 8-12.

17) Gonza'lez S, Rajadhyaksha M, Rubinstein G, Anderson RR (1999) Characterization of psoriasis in vivo by reflectance confocal microscopy. J Med 30: 337-356.

18) González S, González E, White WM, Rajadhyaksha M, Anderson RR (1999) Allergic contact dermatitis: correlation of in vivo confocal imaging to routine histology. J Am Acad Dermatol 40: 708-713.

19) Swindells K, Burnett N, Rius-Diaz F, González E, Mihm MC, et al. (2004) Reflectance confocal microscopy may differentiate acute allergic and irritant contact dermatitis in vivo. J Am Acad Dermatol 50: $220-228$.

20) Busam KJ, Charles C, Lee G, Halperin AC (2001) Morphologic features of melanocytes, pigmented keratinocytes, and melanophages by in vivo confocal scanning laser microscopy. Mod Pathol 14: 862868.

21) Nori S1, Rius-Díaz F, Cuevas J, Goldgeier M, Jaen P, et al. (2004) Sensitivity and specificity of reflectance mode confocal microscopy for in vivo diagnosis of basal cell carcinoma: A multicentre study. J Am Acad Dermatol 51: 923-930.

22) Hofmann-Wellenhof R1, Wurm EM, Ahlgrimm-Siess V, Richtig E, Koller S, et al. (2009) Reflectance confocal microscopy-state-ofart and research overview. Semin Cutan Med Surg 28:172-179.
23) Pellacani G, Longo C, Malvehy J, Puig S, Carrera C, et al. (2008) In Vivo confocal microscopic and histopathologic correlations of dermoscopic features in 202 melanocytic lesions. Arch Dermatol 144: 1597-1608.

24) Bossuyt PM, Reitsma JB, Bruns DE, Gatsonis CA, Glasziou PP, et al. (2003) Towards complete and accurate reporting of studies of diagnostic accuracy: the STARD initiative. BMJ 326: 41-44.

25) NICE Diagnostics Assessment programme manual.

26) Horn M1, Gerger A, Koller S, Weger W, Langsenlehner U, et al. (2007) The use of confocal laser-scanning microscopy in microsurgery for invasive squamous cell carcinoma. Br J Dermatol 156: 81-84.

27) Gerger A, Koller S, Kenn T (2005) Diagnostic applicability of in vivo confocal laser scanning in melanocytic skin tumours. J Invest Dermatol 124: 493-498.

28) Langley RG1, Walsh N, Sutherland AE, Propperova I, Delaney $\mathrm{L}$, et al. (2007) The diagnostic accuracy of in vivo confocal scanning laser microscopy compared to dermoscopy of benign and malignant melanocytic lesions: a prospective study. Dermatol 215: 365-372.

29) Guitera P1, Pellacani G, Crotty KA, Scolyer RA, Li LX, et al. (2010) The Impact of In Vivo Reflectance Confocal Microscopy on the Diagnostic Accuracy of Lentigo Maligna and Equivocal Pigmented and Nonpigmented Macules of the Face. J Invest Dermatol 130: 2080-2091.

30) Longo C, Farnetani F, Ciardo S, Cesinaro AM, Moscarella E, et al. (2013) Is confocal microscopy a valuable tool in diagnosing nodular lesions? A study of 140 cases. Br J Dermatol 169: 58-67.

31) Guitera P, Menzies SW, Longo C, Cesinaro AM, Scolyer RA, et al. (2012) In vivo confocal microscopy for diagnosis of melanoma and basal cell carcinoma using a two-step method: analysis of 710 consecutive clinically equivocal cases. J Invest Dermatol 132: 2386-2394.

32) Curchin CE, Wurm EM, Lambie DLj, Longo C, Pellacani G, et al. (2011) First experiences using reflectance confocal microscopy on equivocal skin lesions in Queensland. Australas J Dermatol 52: 89-97.

33) Methods - Chapter 7: Reviewing and grading the evidence (revised).

34) J2: Example of an evidence table for studies of diagnostic test accuracy.

35) Simundic AM (2008) Measures of diagnostic accuracy: basic definitions. Medical and Biological Sciences. 22: 61-65.

36) Glas AS, Lijmer JG, Prins MH, Bonsel GJ, Bossuyt PM (2003) The diagnostic odds ratio:a single indicatior of test performance J Clin Epidemiol 56: 1129-1135.

37)Mogensen M, Jemec GBE (2007) Diagnosis of nonmelanoma skin cancer / keratinocyte carcinoma: a review of diagnostic accuracy of nonmelanoma skin cancer diagnostic tests and technologies. Dermatol Surg 33:1158-1174.

38) Kollias N, Stamatas GN (2002) Optical non-invasive approaches to diagnosis of skin diseases. J Invest Dermatol Symp Proc 7: 64-75.

39) Gerger A, Koller S, Weger W, Richtig E, Kerl H, et al. (2006) Sensitivity and specificity of confocal laser-scanning microscopy for in vivo dianosis of malignant skin tumour. Cancer 107:193-200.

40) Busam KJ1, Charles C, Lohmann CM, Marghoob A, Goldgeier M, et al. (2001) Detection of intraepidermal malignant melanoma in vivo by confocal scanning laser microscopy. Melanoma Res 12: 349-355.

41) Busam KJ, Hester K, Charles C, Sachs DL, Antonescu CR, et al. (2001) Detection of clinically amelanotic malignant melanoma and assessment of its margins by in vivo confocal scanning laser microscopy. Arch Dermatol 137: 923-929 
42) Langley RG, Rajadhyaksha M, Dwyer PJ, Sober AJ, Flotte TJ, et al. (2001) Confocal scanning laser microscopy of benign and malignant skin lesions in vivo. J Am Acad Dermatol 45: 365-376.

43) Pellacani G, Cesinaro AM, Seidenari S (2005) Reflectance-mode confocal microscopy of pigmented skin lesions - improvement in melanoma diagnostic specificity. J Am Acad Dermatol 53: 979-985.

44) Pellacani G, Guitera P, Longo C, Avramidis M, Seidenari S, et al. (2007) The impact of in vivo reflectance confocal microscopy for the diagnostic accuracy of melanoma and equivocal melanocytic lesions. J Invest Dermatol 127: 2759-2765.

45) Hashemi P, Pulitzer MP, Scope A, Kovalyshyn I, Halpern AC, et al. (2012) Langerhans cells and melanocytes share similar morphologic features under in vivo reflectance confocal microscopy: a challenge for melanoma diagnosis. J Am Acad of Dermatol 66: 452-462.

46) Segura S, Puig S, Carrera C, Palou J, Malvehy J (2007) Dendritic cells in pigmented basal cell carcinoma: a relevant finding by reflectance-mode confocal microscopy. Arch Dermatol 143: 883-886.

47) Segura S, Puig S, Carrera C, Palou J, Malvehy J (2009) Development of a two-step method for the diagnosis of melanoma by reflectance confocal microscopy. J Am Acad Dermatol 61:216-229.

48) Stevenson AD, Mickan S, Mallett S, Ayya M (2013) Systematic review of diagnostic accuracy of reflectance confocal microscopy for melanoma diagnosis in patients with clinically equivocal skin lesions. Dermatol Pract Concept 3: 5-19.

Submit your manuscript to a JScholar journal and benefit from:

- Convenient online submission

ฯ Rigorous peer review

ๆ Immediate publication on acceptance

q Open access: articles freely available online

I High visibility within the field

ब Better discount for your subsequent articles

Submit your manuscript at http://www.jscholaronline.org/submit-manuscript.php 